\title{
Lucutan Plasma Pijar Korona dengan Variasi Tegangan untuk Degradasi Metilen Biru
}

\author{
Kusumandari Kusumandari ${ }^{1}$, Teguh Endah Saraswati ${ }^{2}$, Nor Shalina Saputri ${ }^{1}$ \\ ${ }^{1}$ Program Studi Fisika, Fakultas MIPA, Universitas Sebelas Maret, Surakarta \\ ${ }^{2}$ Program Studi Kimia, Fakultas MIPA, Universitas Sebelas Maret, Surakarta \\ kusumandari@staff.uns.ac.id
}

\section{ABSTRACT}

Plasma technology is considered as promising candidate for wastewater-treatment. In this present work, discharge plasma was generated by two parallel stainless needle electrodes connected with alternating current (AC) high voltage of $8.5-11.5 \mathrm{kV}$. Methylene blue is used as a model solution. The electrode is about $2 \mathrm{~mm}$ above the solution which placed on the magnetic stirrer with a speed of $6 \mathrm{rpm}$. The treatment time were $2,4,6,8$, and $10 \mathrm{~min}$ for each voltage. The characteristics of the solution such as absorbance, temperature and $\mathrm{pH}$ are measured before and after treatment to determine the effect of voltage and treatment time. As results, absorbance and $\mathrm{pH}$ were decrease as voltage and treatment time increased, while the temperature were increase.

Keywords: plasma, wastewater treatment, voltage, treatment time

\section{ABSTRAK}

Teknologi plasma merupakan metode pengolahan limbah yang cukup menjanjikan. Dalam penelitian ini, lucutan plasma dihasilkan dari dua buah elektroda jarum stainless steel yang dipasang paralel dan dihubungkan dengan tegangan tinggi bolak-balik (AC) sebesar $8.5-11.5 \mathrm{kV}$. Metilen biru digunakan sebagai larutan model. Elektroda berada sekitar $2 \mathrm{~mm}$ di atas larutan yang diletakkan pada magnetic stirrer dengan kecepatan 6 rpm. Waktu perlakuan yang digunakan adalah 2, 4, 6, 8, dan 10 menit untuk setiap tegangan. Karakteristik larutan meliputi absorbansi, $\mathrm{pH}$ dan suhu diukur sebelum dan sesudah perlakuan untuk mengetahui pengaruh tegangan dan lama waktu perlakuan plasma. Hasil yang didapat, absorbansi dan $\mathrm{pH}$ turun seiring kenaikan tegangan dan lama waktu perlakuan, sedangkan suhu akan semakin naik.

Kata kunci: plasma, pengolahan limbah, tegangan, waktu perlakuan

\section{PENDAHULUAN}

Zat warna merupakan salah satu permasalahan dalam pencemaran air oleh limbah industri tekstil. Zat warna dengan konsentrasi yang tinggi akan mengganggu kesetimbangan ekosistem air karena menghalangi penetrasi cahaya matahari yang diperlukan makhluk hidup dalam air. Selain itu zat warna tertentu juga bersifat toksik dan menimbulkan bau yang mengganggu kesehatan ${ }^{[1]}$. Sifat toksik yang dimiliki juga dapat menyebabkan mutasi genetik dan berpengaruh pada reproduksi makhluk hidup. Di dalam industri tekstil, zat warrna yang paling sering digunakan adalah metilen biru. Senyawa metilen biru selain bersifat toksik juga memiliki gugus benzena yang sukar terdegradasi ${ }^{[2]}$.

Untuk menghilangkan kandungan zat warna dalam limbah dapat digunakan metode fisika, metode kimia dan metode biologi ${ }^{[3]}$. Salah satu metode yang paling umum digunakan adalah adsorpsi. Selain itu, dapat pula menggunakan metode penangkap lemak (greade trap), sumur pengumpul (sump well) dan biofilter ${ }^{[4]}$. Namun metode-metode tersebut kurang efektif dalam mengurangi konsentrasi dan bau dari limbah. Plasma merupakan teknologi baru untuk melengkapi pengolahan limbah yang sudah ada.

Plasma merupakan gas yang terionisasi dalam lucutan listrik. Proses lucutan listrik yang terjadi akan menghasilkan spesies aktif yang dapat menghilangkan polutan di dalam limbah. Spesies aktif yang berperan dalam penguraian senyawa dalam limbah cair antara lain radikal 
hidroksil $(\mathrm{OH})$ dan hidrogen peroksida $\left(\mathrm{H}_{2} \mathrm{O}_{2}\right)$. Penguraian senyawa dalam limbah dapat terjadi akibat adanya reaksi antara spesies aktif dengan senyawa yang berada di dalam limbah tersebut ${ }^{[5]}$. Efisiensi penguraian oleh plasma dipengaruhi oleh beberapa faktor salah satunya besarnya tegangan yang diberikan ke elektroda ${ }^{[6]}$.

Metode plasma untuk pengolahan limbah dapat berupa plasma lucutan pijar ataupun dielectric barrier discharge (DBD) ${ }^{[7]}$. Pada penelitian ini digunakan metode plasma lucutan pijar karena cukup sederhana dan tidak membutuhkan skema reaktor yang rumit. Larutan metilen biru digunakan sebagai larutan model.

\section{METODE}

Elektroda stainless steel berbentuk jarum dengan diameter $2 \mathrm{~mm}$ diletakkan di atas permukaan metilen biru pada jarak $2 \mathrm{~mm}$. Kedua elektroda dipasang paralel sejauh $2 \mathrm{~cm}$ dan dihubungkan dengan sumber tegangan tinggi $\mathrm{AC}$ dengan variasi tegangan mulai dari 8.50 $\mathrm{kV}$ hingga $11.50 \mathrm{kV}$. Larutan model yang digunakan terbuat dari $6 \mathrm{mg}$ bubuk metilen biru yang dilarutkan dalam $1000 \mathrm{ml}$ aquades. Larutan model diletakkan diatas magnetic stirrer yang diputar dengan kecepatan $6 \mathrm{rpm}$. Variasi waktu perlakuan plasma yaitu 2 menit hingga 10 menit untuk masing-masing variasi tegangan. Karakterisasi absorbansi, $\mathrm{pH}$ dan suhu diukur sebelum dan sesudah perlakuan plasma untuk mengetahui pengaruh tegangan dan lama waktu perlakuan. Skema penelitian ditunjukkan pada Gambar 1.

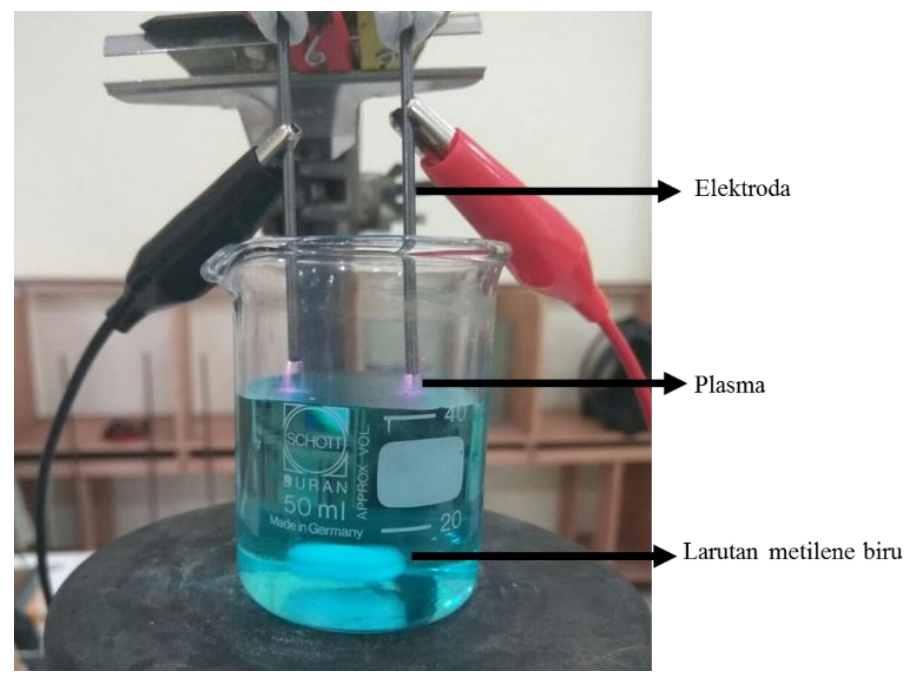

Gambar 1. Skema pengolahan limbah dengan lucutan plasma pijar

\section{HASIL DAN PEMBAHASAN}

\section{Pengaruh Waktu Perlakuan Plasma terhadap Penurunan Absorbansi Larutan Metilen Biru}

Absorbansi menunjukkan jumlah cahaya yang dapat diserap oleh larutan. Semakin besar absorbansi suatu larutan maka semakin besar cahaya yang diserap atau semakin sedikit yang diteruskan. Secara fisik larutan dengan warna yang pekat maka semakin besar absorbansinya, sebaliknya jika warna larutan semakin jernih maka absorbansinya semakin kecil. 
Gambar 2 menunjukkan pengaruh waktu perlakuan plasma terhadap absorbansi dari larutan metilen biru. Plasma dibangkitkan pada tegangan $11,50 \mathrm{kV}$. Control sample adalah absorbansi metilen biru sebelum diberi perlakuan plasma. Dari gambar tersebut terlihat bahwa semakin lama waktu perlakuan semakin besar penurunan absorbansi larutan metilen biru. Hal tersebut dikarenakan semakin lama waktu perlakuan, menyebabkan semakin banyak ionisasi yang terjadi dan spesies aktif yang dihasilkan, sehingga membuat metilen biru semakin banyak yang terdegradasi dan warna larutan metilen biru semakin jernih. Perubahan warna metilen biru dapat dilihat pada Gambar 3.

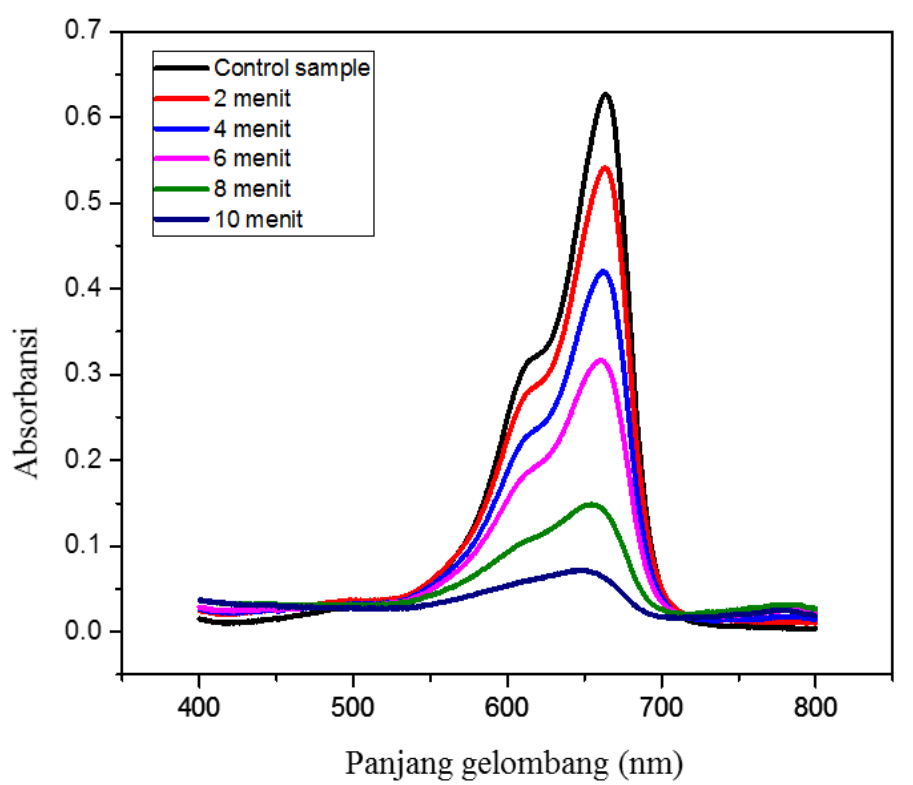

Gambar 2. Pengaruh waktu perlakuan plasma terhadap absorbansi larutan metilen biru

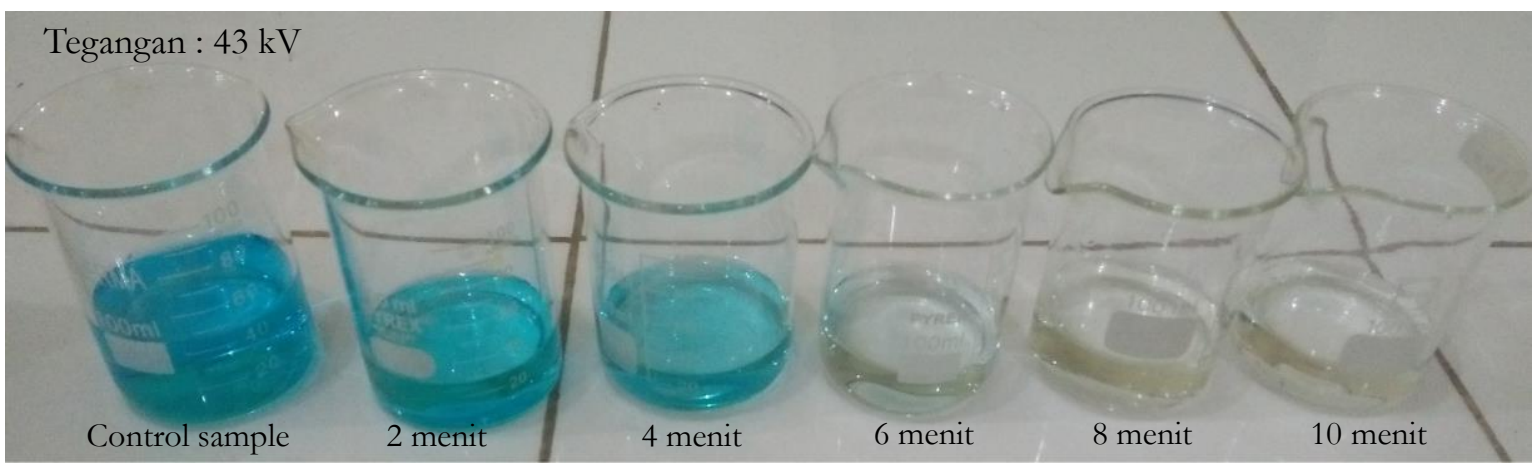

Gambar 3. Pengaruh waktu perlakuan plasma terhadap warna larutan metilen biru

\section{Pengaruh Tegangan terhadap Absorbansi Larutan Metilen Biru}

Pengaruh plasma terhadap konsentrasi larutan metilen biru dapat diwakili dengan membandingkan absorbansinya sebelum dan sesudah perlakuan yang ditunjukkan dengan degradasi. Persentase degradasi dihitung berdasarkan persamaan (1): 


$$
\text { Degradasi }=\frac{\left(A-A_{0}\right)}{A_{0}} \times 100 \%
$$

dimana $A$ merupakan absorbansi setelah perlakuan plasma dan $A_{0}$ adalah absorbansi sebelum perlakuan plasma. Gambar 4 menunjukkan degradasi metilen biru sebelum dan sesudah perlakuan untuk masing-masing variasi tegangan dan waktu.

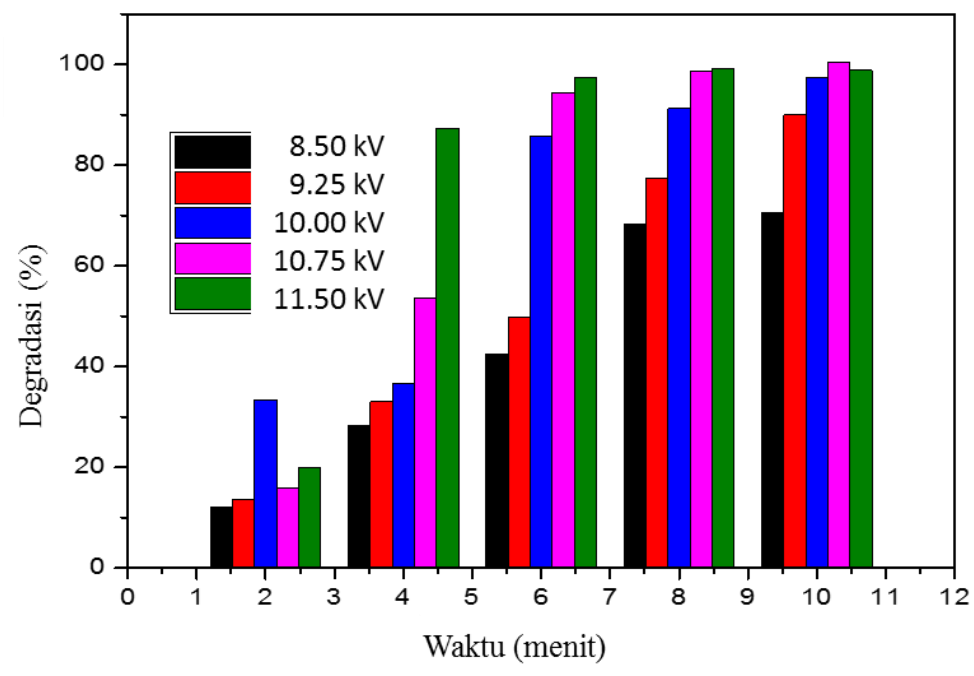

Gambar 4. Degradasi metilen biru sebelum dan sesudah perlakuan plasma untuk berbagai variasi tegangan dan waktu

Dari Gambar 4 terlihat bahwa semakin besar tegangan yang digunakan untuk membangkitkan plasma akan membuat degradasi larutan semakin besar. Sebagai contoh, pada waktu 8 menit, dengan tegangan $8,50 \mathrm{kV}$ degradasi larutan metilen biru adalah $68,22 \%$, kemudian ketika tegangan dinaikkan menjadi $9,25 \mathrm{kV}$ maka degradasi menjadi lebih besar yaitu $77,51 \%$. Peningkatan degradasi terbesar terjadi pada tegangan $11,50 \mathrm{kV}$ yaitu $99,27 \%$. Artinya larutan metilen biru terdegradasi hampir sempurna dan secara fisik berwarna bening. Hal tersebut dikarenakan semakin besar tegangan yang digunakan akan menyebabkan semakin besarnya medan listrik dan intensitas plasma yang terbentuk di sekitar elektroda, sehingga semakin banyak terjadi ionisasi yang menghasilkan lebih banyak spesies aktif sebagai agen degradasi. Hal yang menarik, pada waktu perlakuan 6,8 dan 10 menit, persentase degradasi pada tegangan $10,00-11,50 \mathrm{kV}$ terlihat hampir sama. Hal ini menunjukkan bahwa waktu dan tegangan merupakan faktor yang secara simultan dapat digunakan secara terpisah. Untuk pembangkitan plasma menggunakan tegangan yang besar maka waktu yang diperlukan lebih singkat. Begitu juga jika pembangkitan plasma menggunakan tegangan yang lebih kecil maka diperlukan waktu yang lebih lama untuk menghasilkan besar degradasi yang sama.

\section{Pengaruh Perlakuan Plasma terhadap pH Larutan Metilen Biru}

Besarnya derajat keasaman suatu perairan akan sangat menentukan kelangsungan hidup dari ekosistem didalamnya. Oleh karenanya, karakterisasi $\mathrm{pH}$ dari limbah merupakan faktor penting yang harus diketahui. Pengaruh plasma pada larutan metilen biru ditunjukkan pada 
Gambar 5. Sebelum perlakuan plasma, $\mathrm{pH}$ larutan adalah 6,75. Kemudian menurun menjadi 2,31 setelah perlakuan selama 10 menit.

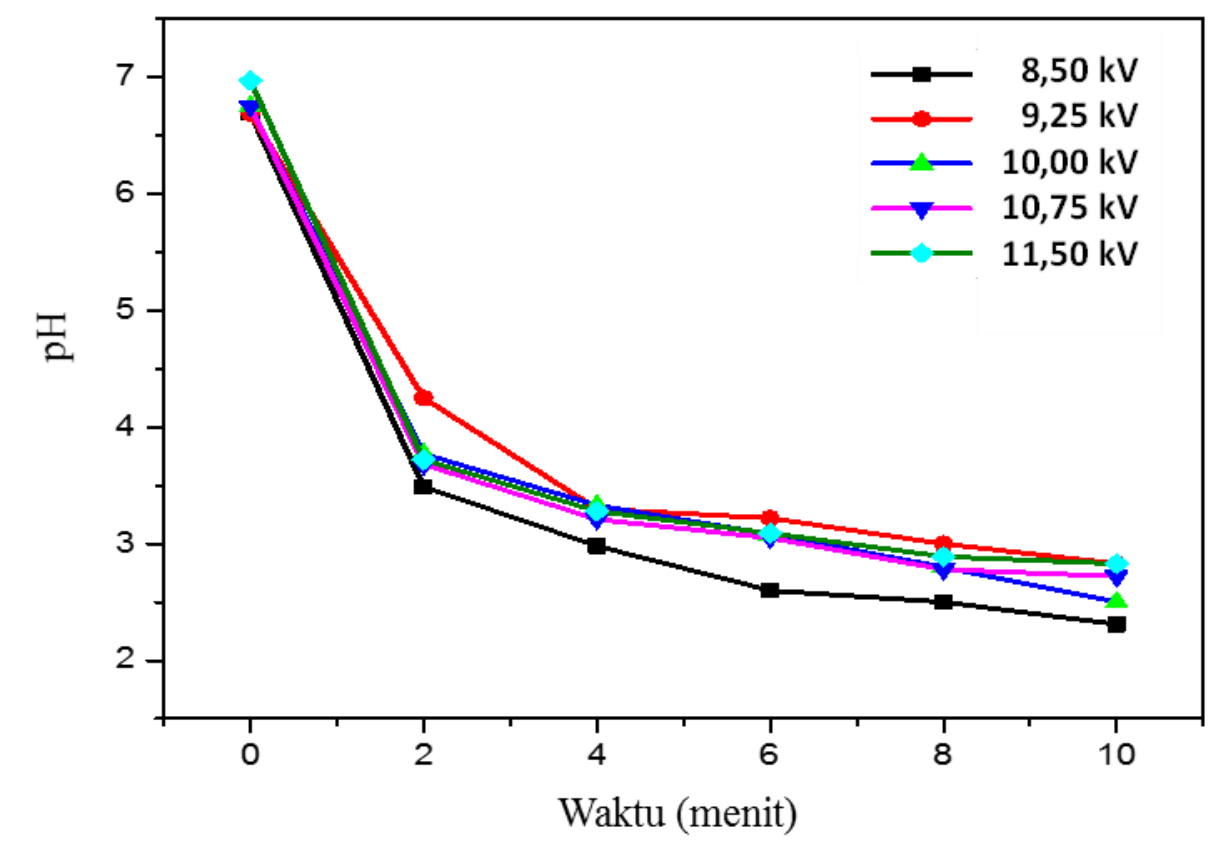

Gambar 5. Pengaruh waktu perlakuan terhadap pH larutan metilen biru

Reaksi antara spesies aktif plasma dengan larutan metilen biru akan menghasilkan senyawa asam, sehingga menyebabkan $\mathrm{pH}$ larutan metilen biru menurun ${ }^{[8]}$. Idealnya, suatu larutan akan aman sebagai tempat hidup jika pH-nya netral (sekitar 7), akan tetapi dari hasil terlihat bahwa larutan metilen biru justru menurun pH-nya setelah perlakuan. Hal ini bukanlah menjadi kontradiksi, karena pada limbah yang sesungguhnya terdiri dari berbagai macam zat warna yang kemungkinan $\mathrm{pH}$ awal bisa lebih besar, sehingga ketika diberi perlakuan plasma, maka pH-nya akan menjadi lebih kecil atau menuju netral.

\section{Pengaruh Perlakuan Plasma terhadap Suhu Larutan Metilen Biru}

Kemudian parameter lain yang sangat penting adalah suhu. Suhu larutan metilen biru sebelum perlakuan yaitu $27,1^{\circ} \mathrm{C}$, sedangkan suhu larutan setelah perlakuan mencapai $62,3^{\circ} \mathrm{C}$ pada waktu 10 menit dan tegangan $11,50 \mathrm{kV}$, seperti terlihat Gambar 6. Tumbukan antar elektron akan mempengaruhi suhu larutan metilen biru. Semakin tinggi tegangan akan menyebabkan semakin besarnya medan listrik yang memicu banyaknya elektron yang bertumbukan karena hasil pelipatgandaan elektron yang semakin besar ${ }^{[9]}$. Selain itu, semakin lama waktu perlakuan maka semakin banyak perulangan tumbukan antar elektron sehingga suhu semakin naik. 


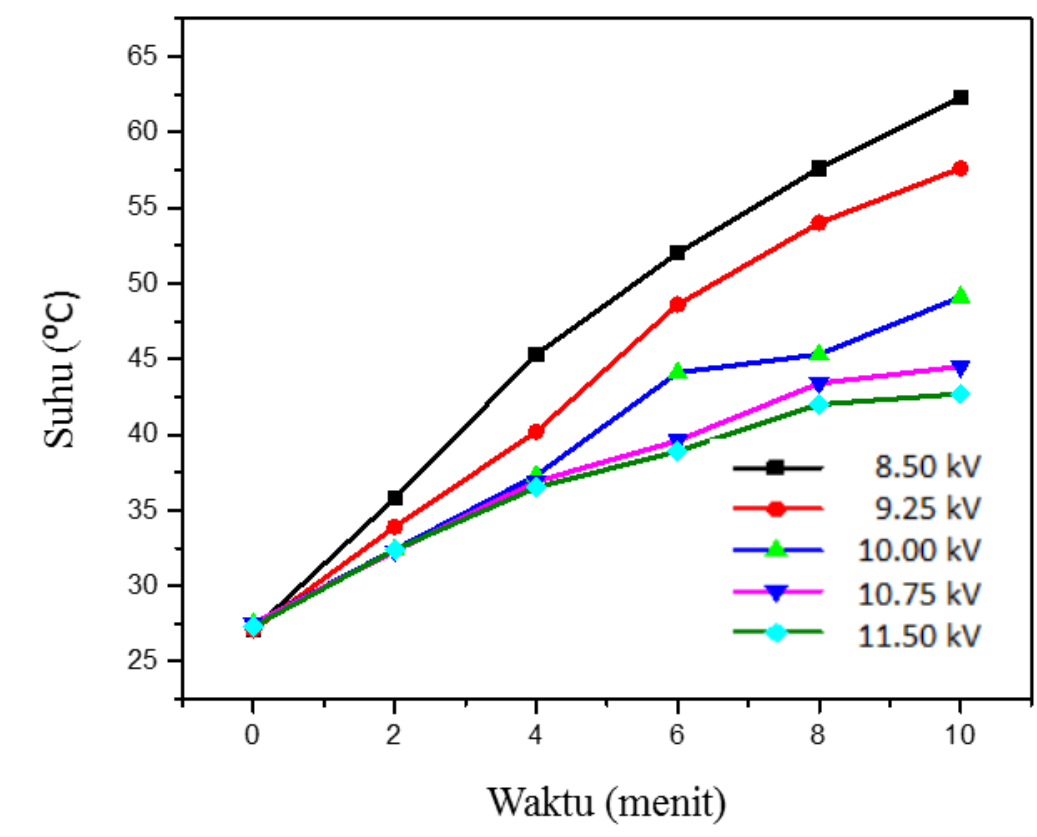

Gambar 6. Grafik pengaruh lama waktu perlakuan plasma terhadap suhu larutan metilen biru

\section{KESIMPULAN}

Besarnya tegangan akan mempengaruhi besarnya medan listrik disekitar elektroda. Medan listrik yang besar akan menarik keluar elektron dari elektroda. Semakin besar medan listrik maka semakin banyak elektron yang keluar sehingga meningkatkan ionisasi. Ionisasi menghasilkan spesies aktif yang akan mendegradasi larutan metilen biru. Semakin tinggi tegangan dan waktu perlakuan maka degradasi metilen biru yang dihasilkan semakin besar, suhu meningkat, dan $\mathrm{pH}$ menurun.

\section{REFERENSI}

1 Sanada, R. A., Moersidik, S. S., \& Suwartha, N., 2014, Adsorpsi Zat Warna Kationik (Methylene Blue) Menggunakan Karbon Aktif Tempurung Kelapa dan Batu Bara serta Efisiensi Regenerasinya.

2 Falahiyah, 2015, Adsorpsi Methylene Blue menggunakan Abu dari Sabut dan Tempurung Kelapa Teraktivasi Sulfat, Skripsi, Malang, Universitas Islam Negeri Maulana Malik Ibrahim.

3 Holkar, R.C., Jadhav, J.A., Pinjari, V.D., \& Mahamuni, M.N. 2016. A Critical Review on Textile Wastewater Perlakuans: Posisble Approaches. Journal of Environmental Management, 182, 351-366.

4 Widyaningsih, V. 2011. Pengolahan Limbah Cair Kantin Yogma FISIP UI. Skripsi. Departemen Teknik Lingkungan UI.

5 Hadiwidodo, M., Huboyo, S.H., \& Indrasarimmawati. 2009. Penurunan Warna, COD dan TSS Limbah Cair Industri Tekstil Menggunakan Teknologi Dielectric Barrier Discharge dengan Variasi Tegangan dan Flow Rate Oksigen. Jurnal Presipitasi, 7(2), 16-22. 
6 Jiang, B., Zheng, J., Qiu, S., Wu, M., Zhang, Q., Yan, Z., \& Xue, Q. 2014. Review on Electrical Discharge Plasma Technology for Wastewater Remediation. Chemical Engineering Journal, 236, 348-368.

7 Nur, M. 2011. Fisika Plasma dan Aplikasinya. Semarang : UNDIP.

8 Muradia, S. \& Nagatsu, M., 2015, Study Of Low-Voltage Pulsed Plasma Discharges Inside Water Using A Bubble-Generating Porous Ceramic Electrode For Wastewater Perlakuan, Applied Physics Letters 102, 144105.

9 Wardaya, A. Y. \& Nur M, 2010,Analisis Medan Listrik pada Plasma Korona dengan Konfigurasi Cincin Bidang, Berkala Fisika. 13 (4), 139-144. 